\title{
Geochemical Anomalies in the NW Flank of Gedabek Mine (Lesser Caucasus, Azerbaijan)
}

\author{
Baba-Zadeh Vasif ${ }^{1}$, Mursalov Samir ${ }^{2}$, Veliyev Anar ${ }^{3}$, Imamverdiyev Nazim ${ }^{4 *}$, Abdullayeva \\ Shakhla ${ }^{5}$, Bayramov Aydin ${ }^{6}$, Talibov Mehman ${ }^{7}$ \\ ${ }^{1}$ Baku State University, Prof. \\ ${ }^{2}$ Azerbaijan International Mining Company Limited, Doctoral Student \\ ${ }^{3}$ Azerbaijan International Mining Company Limited, Ph.Dr. \\ ${ }^{4}$ Baku State University, Prof. \\ ${ }^{5}$ Baku State University, Associate Prof. \\ ${ }^{6}$ Azerbaijan International Mining Company Limited, Doctoral Student \\ ${ }^{7}$ Azerbaijan International Mining Company Limited, Doctoral Student
}

*Corresponding Author: Imamverdiyev Nazim, Baku State University, Prof.

\begin{abstract}
The article discusses the features of the geochemical anomalies of the northwestern part of the Gedabek district, obtained in recent years by employees Azerbaijan International Mining Company Limited. E article discusses the features of the geochemical anomalies of the northwestern part of the Kedabek field, obtained by employees in recent years. As a result of these studies, new promising areas have been discovered, such as Qadir, Umid, Mubariz, and others.
\end{abstract}

Keywords: geochemical anomalies, Gedabek district, Lesser Caucasus, Azerbaijan

\section{INTRODUCTION}

Gedabek ore district is located in the territory of Shamkir uplift of the Lok-Karabakh structuralformation zone in the Lesser Caucasus Mega-anticlinorium. The ore region has a complex geological structure, and it has become complex with the intrusive masses and breaking structures of different ages and different composition. Lower Bajocian is essentially composed of an uneven succession of diabase and andesitic covers, agglomerate tuffs, tuff-gravelites and siltstones. Tuff of the Lower Bajocian were exposed to strongly metamorphism (skarn alteration and hornfelsed) as a result of the impact of Upper Bajocian volcanism and intrusive of Upper Jurassic age. Only sub volcanic facie of the Upper Bajocian in the Gedabek Mine has been studied (rhyolite and rhyodacite, quartz-porphyry). Rocks related to the Bathonian stage have developed mainly in the northern and southern edges of Shamkir uplift.

Gedabek ore district and Shamkir uplift in general is complex in terms of its tectonic structure and its magmatism is complex too. Magmatic processes in this region have occurred intensely. There are 3 phases of magmatism in the ore area: Bajocian, Bathonian and Upper Jurassic phases. The Bajocian phase is divided into two autonomous sub-stages: Lower Bajocian age rocks - intermediate and basic composition pyroclastic volcanic and volcanic disturbed rocks - occupy the central portion of Shamkir uplift, and have become complex with intrusive and sub volcanic complexes and breaking structures of different ages, morphology. Acid composition products of the Upper Bajocianmagmatism are represented very broad by all facies within Gedabek ore district. It can be considered that the magmatic centre of the Upper Bajocian period is located in the Shamkir uplift. Andesite, partially andesite-basalt composition products of the Bathonian phase of magmatism, as well as various composition pyroclastic materials and lava flows Upper Jurassic phase are spread mainly in the sidelines of Shamkir uplift. Along the breakings structures and in the areas between them, rocks along micro cracks have become strongly quartizated, kaolinized, sericitized and in most cases changed to secondary quartzite. Breaking structures have not caused Lower Bajocian rocks to become 
too complex. The main complexity were generated by sub volcanic masses of rhyolite, rhyodacite and quartz-porphyry composition of Upper Bajocian age which occurred along the Gedabek-Bittibulag depth fault and which began to cool down in the area close to the surface. These magmatic masses were deprived of high pressures but were in contact with the magmatic source which had not yet cooled down. High temperature hydrothermal solutions that were separated from the magmatic source moved along the sub volcanic mass cracks and contacts and created hydrothermal metasomatic alterations of various types within them and in the surrounding rocks. Rhyolites and rhyodacites changed to various types of secondary quartzite, and the surrounding rocks changed into secondary quartzite, skarn rocks and hornstones depending upon petro graphic, mineralogical and litho logical compositions.

However the processes mentioned above did not occur all through the sub volcanic masses and contact rocks. These processes occurred in such areas where there was a constant contact (open channel or open contact zone) between the subvolcano and magmatic source. One of such areas was the Misdag area in which Gedabek mineral deposit (mine) is located. When sub volcanic masses began to cool down dynamic forces constantly influenced some of its regions, in particular the regions that were in active contact with the sub volcanic source, and dense crack points and damage regions started to emerge here. Such regions were very favourable for the movement of hydrothermal solutions that were rich in chemical elements. In subsequent stages, hydrothermal solutions which were separated from the magmatic centre and moved along the sub volcanic cracks and contact areas led to the creation of golden copper-pyrite stocks of different sizes emerging along the upper contact of the subvolcano. Created inside the secondary quartzite in the areas with few cracks and no upper closed screens tiny chords around these stocks limited ore masses.

\section{SAMPLE LOCATION AND SAMPLING MeTHODS}

The coordinates of soil samples were imported to Garmin software and samples location was founded by GPS. The current accuracy of portable GPS receivers is sufficient for sample sites to be located using this method. Locations, sample numbers and site descriptions can be entered into a suitable database or GIS platform.

For most soil sampling surveys, 300-500 gr samples are sufficient although larger samples $(2-3 \mathrm{~kg})$ may be collected for duplicate and other purposes. Collected samples are generally placed in chemical-free paper (geochemical) bags suitable for air drying or drying in an oven. Sampling and field sieving was conducted in areas free from wind-blown contaminants, away from roads, fences, buildings, dams, and away from active mine sites.

\subsection{Sampling Steps}

- Locate sample sites with GPS receiver and enter into database/GIS platform;

- Record the horizon ("B" or soil);

- Record the color of horizon, rock at the bottom of horizon;

- Estimate the clast size of rock fragments;

- Digging the hole in $1 \mathrm{~m}$ diameter area and take a sample with plastic shovel. A sample of approximately $2 \mathrm{~kg}$ is sufficient;

- Sieve out the coarse pebbles, sticks, etc. (greater than 1 or $2 \mathrm{~cm}$ ) on to a plastic sheet and pick out any obvious organic material or alternatively this can be floated off by washing the lag in water prior to sample preparation.

\subsection{Sample Preparation at the La Boratory}

Soil samples were pushed through a sieve. Sieve fractions finer than -80 mesh were dried at the heater (temperature $50^{\circ}$ ). The relatively bigger fractions were removed from sieve. Dried samples were submitted in Kraft paper bags and locked to avoid any dust and particles impaction into samples. Then samples were analyzed by XRF Thermo Nithon equipment and got ready to send these samples ALS laboratory.

\subsection{Method of Sample Analysis}

Au was first analyzed by Au-TL44 (Trace Level Au). If during this method analyzing Au shows the value $>=1.00 \mathrm{ppm}$ then run the method Au-AROR 44 . 
The second method is ME-MS41L, which is including into Aqua Regia ICPMS. This method is commonly used because it will dissolve elemental gold, as well as breakdown iron and manganese oxides/hydroxides, carbonates, sulfates, sulfides and many clays. We used in our database the values of ME-MS41L, because the Au detection limit in this method is lower than Au-TL44.

\subsection{Sampling Method and Approach}

The MMI sampling and assays were done consistently for each survey and all assays at the same laboratory. Samples were collected $30 \mathrm{~cm}$ below the true soil interface. Attention was done not to vary depth beneath true soil interface. Attention was done to collect sample in a consistent manner.

For this sampling we took samples (called T-samples) from the same points where we took our previous samples for horizon "B"

Equipment

- A $30 \mathrm{~cm}$ diameter plastic sieve with minus $5 \mathrm{~mm}$ apertures;

- Plastic collection dish with similar diameter brush used for cleaning the sieve and dish between samples;

- A bare steel (no paint) garden spade;

- Paper snap seal bags, A 250- 300 gr sample is collected and stored in bag (a 90mm x 150mm plastic seal sample bag is recommended). Once seal in the bags, samples should placed in secure place. Sample sites are away from any major contamination.

\section{IDENTIFIED ANOMALY AREAS}

There are carried out soil-geochemical surveys in the Licence Area on the NW of the Gedabek Mine by GEG. Based on interpretation of structural-litho logical following preliminary identification of five areas of interest within the $3 \mathrm{~km}^{2}$ licence:

1. Gadir Gallery Area;

2. Gadir Area;

3. Umid Area;

4. Mubariz Area;

5. AC Area (Fig.1).

Previously reported results (by GEG, 2014 year), together with the latest geochemical data integrated with litho logical-structural, grab sampling, alteration data, are summarized below.

We are identified several soil geochemical anomalies besides top ore perspective areas in the NW Flank of the Gedabek Mine: Zirve Area; Zefer Area; other geochemical anomalies (A, B, C, D, E, F, G, H, I, J \& L).

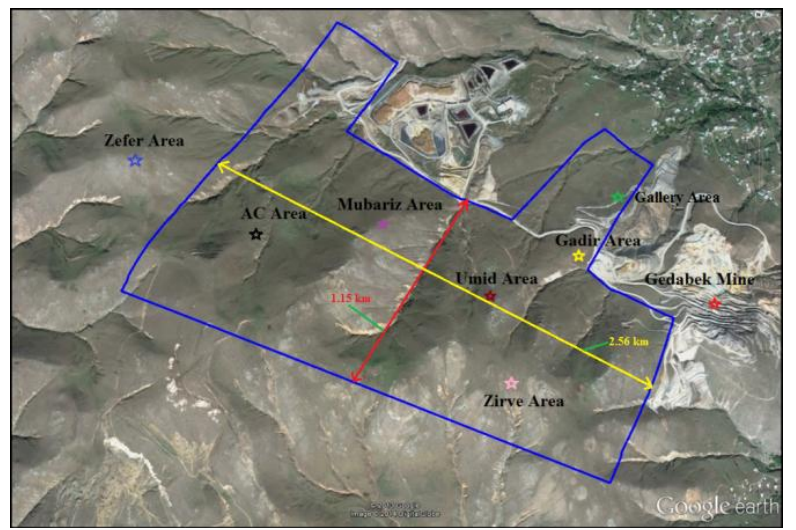

Figure1. Contur of soil geochemical sampling area in the NW Flank of the Gedabek Mine.

\subsection{Gedabek Mineral Deposit}

The Gedabek deposit is one of the main producing mining of the Gedabekore district Azerbaijan, and is the largest porphyry-epithermal ore field of the country. It belongs to the Lesser Caucasus, located in the central part of the Tethys metallogenic belt. It is emplaced within the Jurassic-Cretaceous LokKarabakhmagmatic arc, resulting from the subduction of the Tethys Ocean along the Eurasian margin. 
More detailed study of fund and published data and our own persistent investigations allow us to redetermine the geological-economic type and specify a scale of the object - it should be looked upon as a large deposit of complex ores of base, precious and rare metals of gold-porphyry-copper class. As a result of our researches the Gedabek deposit should be regarded as a large stock work of relatively streaky-disseminated gold-porphyry-copper ores, representing a considerable part (more than 90\%) of its reserves. The large stock work ore body encloses lenses, lens-stocks and stocks of previously and partly mined "high grade" gold-copper-pyrite ores mainly located close to surface section. Mineralization of porphyry type is superimposed on pyrite ores. The ore-enclosing rocks are secondary quartzites. Sub volcanic rhyolite-dacitic porphyries compose a large stock work body elongated in northwest-southeast direction at dimensions as extension greater than $1800 \mathrm{~m}$, width 200 $1000 \mathrm{~m}$ (greater than $600 \mathrm{~m}$ on average) and development of sulfide mineralization related to goldcopper-porphyry type in depth $240-300 \mathrm{~m}$.

Location of Gedabek deposit of gold-copper-porphyry ores (on the basis of which experts separated "Gedabek type of copper deposits" in the Lesser Caucasus) in the contract area serves as reliable prospecting criterion on presence of single-type and complex ore deposits of noble, nonferrous and rare metals within this area.

Underground mining activity at Gedabek started about 200 years ago, and is more recently exploited for copper, silver and gold. The deposit was previously described as porphyry of the $\mathrm{Cu}$ or $\mathrm{Cu}-\mathrm{Au}$ type, and, more recently, as high-sulphidation epithermal deposit. The ore mineralization is hosted by a large body showing an upper flat-lying contact with Bajocian-Bathoni an andesitic tuff and located above a Kimmeridgian diorite intrusion. The ore body has a porphyritic texture formed by quartz eyes in a microcrystalline matrix. This study questions the primary magmatic nature of the ore body and proposes a formation by a hydrothermal quartz \pm adularia \pm pyritealteration.

The field study in the open pit reveals a pervasive propyllitic alteration of the andesitic tuff and a pervasive quartz \pm adularia \pm pyritealteration which forms the ore body. Field observations also reveal a strong litho logical control of the propyllitic and the quartz \pm adularia \pm pyritealterations, within sub horizontally bedded volcanoclastic rocks. The central part of the open pit is characterized by the intersection of two main fault structures spatially associated with a late argillic alteration extending vertically, and small semi-massivesulphide mineralization.

Metal content analyses of the quartz \pm adularia \pm pyrite alteration and mineralizations indicate a large low grade ore body associated with the pervasive quartz \pm adularia \pm pyritealteration, and high grade semi-massive sulphur mineralizations associated with the central part of the deposit. Variable but high contents of volatile elements ( $\mathrm{Te}, \mathrm{Se}, \mathrm{Hg}, \mathrm{Sb}, \mathrm{As})$ indicate a shallow epithermal environment of formation.

A petro graphic study of mineralization describes a par genetic sequence subdivided in four stages: (1) an early quartz-adularia-pyrite assemblage, forming a pervasive alteration of the andesitic tuff and a localized mineralization occurring as semi-massive sulphide lenses, followed by (2 ) a chalcopyritesphalerite-dominated mineralization occurring as localized semi-massive lenses and veins; (3) a late copper stage characterized by the replacement of chalcopyrite and sphalerite by chalcocite, covellite and enargite; and (4) a finely disseminated galena-tennantite dominated mineralization, with an ambiguous timing of formation.

Microprobe analyses, undertaken on sphalerite from the chalcopyrite-sphalerite-dominated mineralization, indicate a general intermediate-sulphidation state of the system, with large variations between the low-intermediate limit and the intermediate-high limit of sulphidation state suggested by Einaudi et al. (2003year). The detailed petro logical study indicates a general increase of the sulphidation state of the system with time, from a low-intermediate-sulphidation state toward a highsulphidation state.

Sulphur isotope data obtained for sulphides and sulphates from the Gedabek mineralizations indicate a magmatic source of sulphur precipitated in a general reduced environment. A preliminary oxygen isotope study of the Gedabek ore body is consistent with a quartz \pm adularia \pm pyrite alteration of the andesitic tuff.

The combination of data provided by the company exploiting the Gedabek deposit, field observations, geochemistry, metal content analyses, a detailed petrography, microprobe analyses, X-ray diffraction 
analyses, sulphur and oxygen isotope analyses allows us to propose an evolution in time and space from an early and large low-intermediate-sulphidation hydrothermal system toward a later and more focused intermediate-high-sulphidation system at Gedabek.

The superposition of these two distinct groups of epithermal systems are possibly formed by unrelated hydrothermal events. However, a model of formation by a single continuous hydrothermal system cannot be discounted and is also discussed.

This deposit is still controversial, and previously, it was classified as a porphyry deposit, and more recently as a high-sulphidation epithermal deposit. The ore body consists of a pervasive quartz \pm adularia \pm pyrite alteration localized between Middle Jurassic andesitic volcanoclastic rocks and a Late Jurassic diorite intrusion.

This study aims at constraining the tectonic setting of the deposit using litho geochemistry of the various magmatic country rocks, characterizing the hydrothermal alteration and the ore paragenesis, as well as the nature of the fluids involved in the ore formation processes.

Geochemistry of the Gedabek ore district suggests a calc-alkaline subduction-related magmatic setting, with basaltic to andesitic compositions. Our study questions the primary magmatic nature of the so-called "quartz-porphyry" intrusion, which hosts the mineralization, and proposes that this rock is the product of extensive quartz \pm adularia \pm pyrite alteration.

Three main alteration types are observed at Gedabek: a propylitic alteration of tuff, surrounding the ore body; a pervasive quartz \pm adularia \pm pyrite alteration which forms the ore body and has a flatlying contact with tuff; and an argillic alteration spatially associated with fault structures in the central part of the deposit. Field observations reveal a strong litho logical control of the propylitic and the quartz \pm adularia \pm pyrite alterations, within sub horizontally bedded volcanoclatic rocks.

Four stages are described in the par genetic sequence: an early quart-pyrite-adularia assemblage, followed by a chalcopyrite-sphalerite-dominated mineralization, a late copper stage represented by chalcocite, covellite and enargite, and a galena-tennantite- dominated mineralization, with an ambiguous timing.

Alteration and mineralization types record an evolution in time and space from an early and widespread low-intermediate-sulphidation system toward a later and local intermediate-high sulphidation system. The mineralization style and metal content analyses also indicate a transition from a low grade widespread disseminated mineralization toward local and small semi- massive sulphide lenses.

Sulfur isotope data are consistent with a magmatic source for sulfur. Variable but high contents of volatile elements ( $\mathrm{Te}, \mathrm{Se}, \mathrm{Hg}, \mathrm{Sb}, \mathrm{As}$ ) indicate a shallow epithermal environment. The combination of oxygen isotopic compositions and whole rock geochemistry, based on immobile elements, of the ore body are consistent with a low temperature quartz \pm adularia \pm pyrite alteration of andesitic rocks.

The superposition of these two distinct groups of epithermal systems is still open to debate. Either they may have formed during two unrelated hydrothermal events, or during a single and continuous evolution of the same hydrothermal system, which is the preferred model proposed in this study.

\subsection{Gadir Gallery Area}

Gadir Gallery Area is located in the northward (approximately 280m) from Gedabek Mine, at the north-east end of the Gadir Area. Elements with anomalous concentrations include $\mathrm{Au}-\mathrm{Ag}-\mathrm{As}-\mathrm{Zn}-\mathrm{Pb}-$ Mo-Te-Ba (fig.2). The Area is located on the outcrop of sub volcanic rhyolite and nearly Gedabek intrusion.

Based facts mentioned above on the Gadir Gallery Area have drilled some drill hole. Drill holes AIMCDD53 and AIMCDD57 were drilled to investigate gold values which had been located on the outcrop sub volcanic rhyolite. Both drill holes intercepted mineralization zone, particular drill hole AIMCDD53 intersected zone thickness $0-29 \mathrm{~m}$ intervals, average $\mathrm{Au}=0.63 \mathrm{ppm}, \mathrm{Ag}=3.28 \mathrm{ppm}$, $\mathrm{Cu}=0.03 \%, \mathrm{~Pb}=120 \mathrm{ppm}, \mathrm{Zn}=256 \mathrm{ppm}$. Drill hole AIMCDD57 also intercepted a mineralized zone, $\mathrm{Au}$ values is $0.3 \mathrm{ppm}, \mathrm{Ag}=1.58 \mathrm{ppm}, \mathrm{Cu}=0.03 \%, \mathrm{~Pb}=85 \mathrm{ppm}, \mathrm{Zn}=1109 \mathrm{ppm}$ for $30-75 \mathrm{~m}$ intervals.

\subsection{Gadir Area}

Gadir area is located in 400 meters from the current pit. The area was first time discovered during the structural-geological mapping at the flank of Gedabek mineral deposit by the geological 
consultant AllahverdiAgakishiyevand Gedabek Exploration Group (GEG). Here is the outcrop of quartz porphyry sub volcanic formation on the surface was considered as the main factor. In the aim of discovering the ore formation in contact part of this sub volcano was drilled AIMCDD86 drill hole in 2012 year.

The mineralization is deeper than that currently Gedabek deposit however its surface elevation is higher. The top elevation of the mineralized zone is 150 meters deeper than the top elevation of mineralization in the northern portion of the main Gedabek Pit.

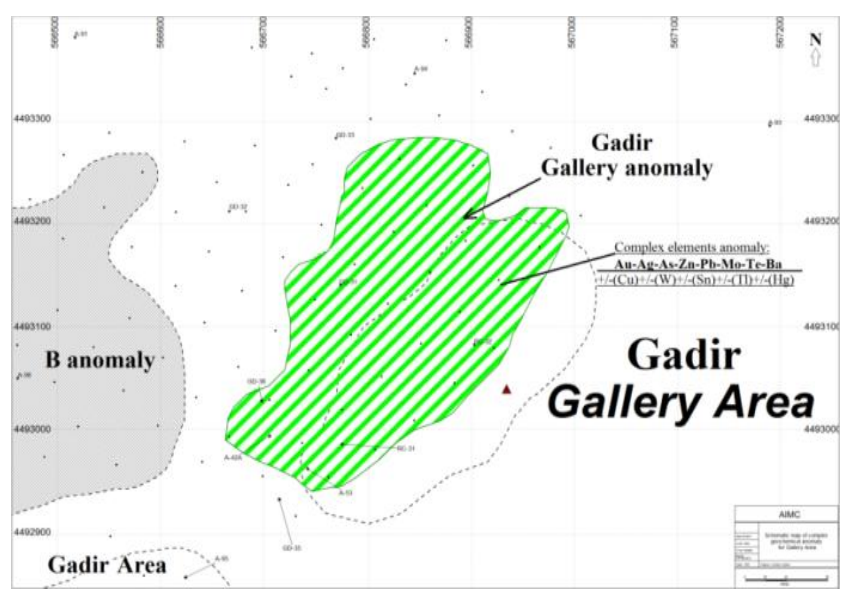

Figure2. Soil geochemical anomaly map for complex elements of the Gadir Gallery Area.

In the Gadir area was drilled 11 drill holes. The first drill hole was AIMCDD86, which intercepted the ore from 226 to 250 meters. Then was drilled AIMCDD 106, 107 and 108. The ore is located in the contact between volcanic rocks and the quartz porphyry (rhyolite-rhyodacite sub volcanic formation). The lithology is different than the surface. There are some dissemination, breccia and vein-like hydrothermal structures (High Sulphidation System) in the quartz porphyry. The ore mineralization is represented by disseminated, lens shape and vein-type of pyrite, chalcopyrite, sphalerite, galena, magnetite and etc. The AIMCDD106 drill hole intercepted the massive sphalerite in association with pyrite and chalcopyrite, AIMCDD107 drill hole intercepted also massive chalcopyrite zone. The oreenclosing rocks are hydrothermal altered quartz porphyry. The morphology of the ore body is like stock work form.

In the Gadir area was drilled 11 drill holes. The first drill hole was AIMCDD86, which intercepted the ore from 226 to 250 meters. Then was drilled AIMCDD 106, 107 and 108. The ore is located in the contact between volcanic rocks and the quartz porphyry (rhyolite-rhyodacite sub volcanic formation). The lithology is different than the surface. There are some dissemination, breccias and vein-like hydrothermal structures (High Sulphidation System) in the quartz porphyry. The ore mineralization is represented by disseminated, lens shape and vein-type of pyrite, chalcopyrite, sphalerite, galena, magnetite and etc. The AIMCDD106 drill hole intercepted the massive sphalerite in association with pyrite and chalcopyrite, AIMCDD107 drill hole intercepted also massive chalcopyrite zone. The oreenclosing rocks are hydrothermal altered quartz porphyry. The morphology of the ore body is like stock work form.

Gadir ore-controlling faults (fig.3): the later concerning the described systems of the faults within the deposit bounds are the sub-latitudinal faults having a northwest strike $\left(270-310^{\circ}\right)$ and a steep dip to the south $\left(80-85^{\circ}\right)$. The thickness of these faults doesn't exceed $50 \mathrm{~m}$. The rocks along these faults are brecciate, slightly schistose and kaolinized.

The second parallel fault passes through north of the previous fault along a north flank of Gadir mineralization area. On a map both faults change a strike from the west $\left(270^{\circ}\right)$ to the northwest $\left(310^{\circ}\right)$, are turned by a concave side to the north towards a sub volcanic body of rhyolite-dacites and have a semi-annular character. Along these fault is observed a vertical displacement of rocks. The north blocks are down about $60-75 \mathrm{~m}$ concerning the south blocks. All described systems of the faults are pre-mining and divide the deposit into the separate blocks dislocated along a vertical line at different levels concerning one another and formed a small dome-like elevation.

Gadir Area is anomalous in a number of elements including Au-Ag-Pb-Sn-Sb (fig. 4). 


\subsection{Umid Area}

Umid area is located in $0.6 \mathrm{~km}$ to the West from Gadir area. It is situated between two faults and looks like horst (fig.3, 5). In geological point of view it consists of lava facies of quartz-plagioporphyrite (rhyolite-dacite porphyry) of Upper Bajocian age. Above this facies situated upper volcanoclastic strata of Bathonian stage which consist of tuff-breccias, tuff-conglomerates of andesite porphyritic composition.

There were taken samples from the surface during soil geochemical sampling. The more significant assay results and coordinates of the channel samples. The samples were taken from soil horizon "B" (limonite, kaolin, magnetite and etc.)

The Umid area is divided to five anomalies (tab. 1): I. East Part; II. North Part; III. NW Part; IV. West Part; V. South Part.

\subsection{Mubariz Area}

Mubariz area is located to the North-West from Umid and Gadir areas in 0.4-1.0 km (fig.6). The geological composition of rock is the same with Umid area. During the mapping there were occurred the silicified tuffs within malachite fragments. Also there were taken the soil geochemical samples by Gedabek Exploration Group (GEG). There are some anomal soil geochemistry results of $\mathrm{Zn}, \mathrm{Sb}$ and Hg elements.

The Mubariz area is divided into five anomalies: (tab. 2): I. NE Part; II. North Part; III. West Part; IV. East Part; V. SW Part; VI. South Part.

\subsection{AC Area}

$\mathrm{AC}$ area is located to the North-West from Umid and Gadir areas in 1.18-1.7 km (relatively) as well as located in $0.7 \mathrm{~km}$ to the West from Mubariz area (fig. 7). This area is bordered between one Shekarbek-Gedabek regional fault, and two local faults. In geological point of view it consists of upper volcanoclastic strata, tuff-breccia porphyry, tuff-conglomerate, andesite porphyry tic rocks of Bathonian stage. All this complex of rocks is crossed by sub volcanic of rhyolite and rhyolitic-dasitic composition. This sub volcanic formation is strongly hydrothermally altered. During the mapping there were occurred the strongly silicified tuffs within malachite fragments. Also there are high assay results for $\mathrm{Ag}$ (>20ppm in 3 samples) in soil (from horizon "B") samples taken from AC area.

The AC Area contains several geochemical anomalies (tab. 2): I. NE Part; II. North Part; III. NW Part; IV. Centre Part; V. East Part; VI. SW Part; VII. South Part.

\subsection{Zirve Area}

Zirve Area is located in top of the Yogundag Mountain. Andesite, andesite-basalt tuffs and tuff sandstone are most spreaded in this area. The Zirve Area contains four geochemical anomalies: I. East Part; II. North Part; III. Centre Part; IV. West Part.

\subsection{Zefer Area}

Zefer Area is located in the between Yogundag and Gyzyldjadag Mountains and extends to westward Leach Pad, in the north corner of the AC Area. Elements found in anomalous concentrations are $\mathrm{Au}$ As-Pb-W-Cs-Ba (fig. 9).

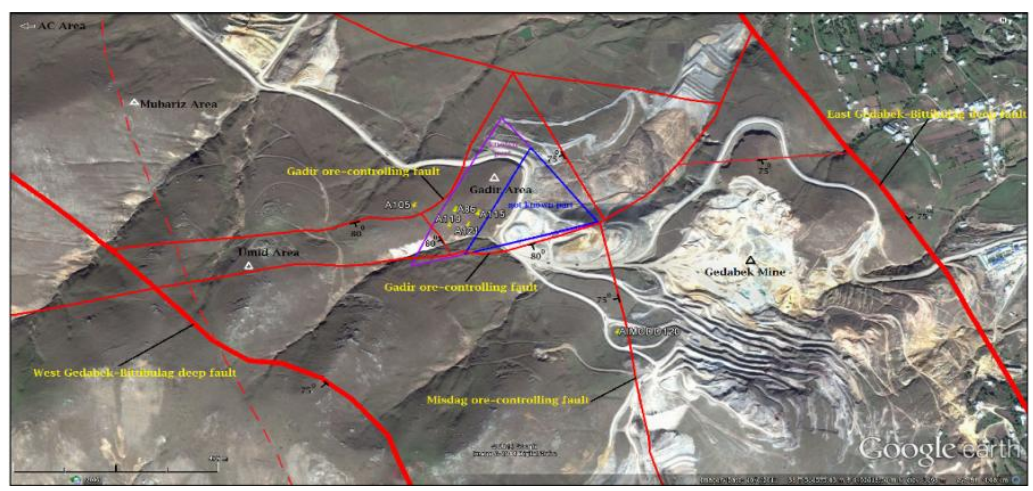

Figure3. Schematic structural map of the Gadir Area (on Google Earth). 


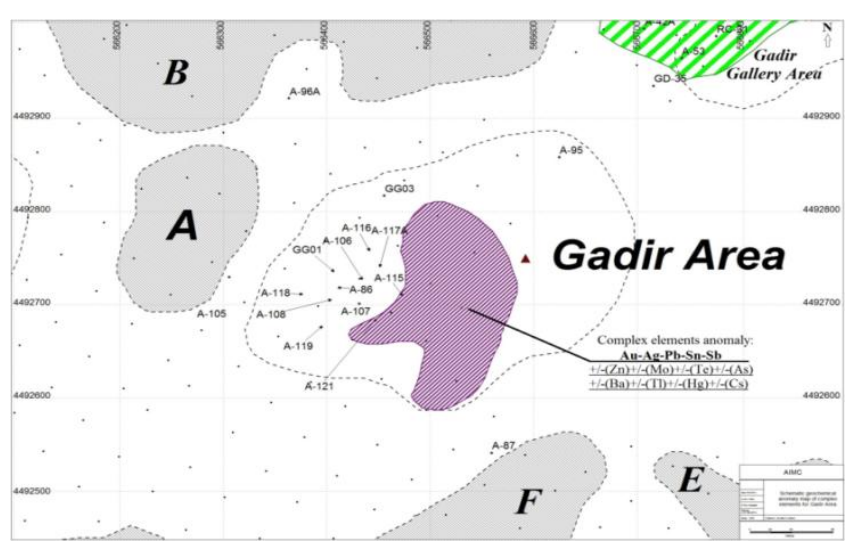

Figure4. Soil geochemical anomaly map for complex elements (violet color polygon) of Gadir Area.

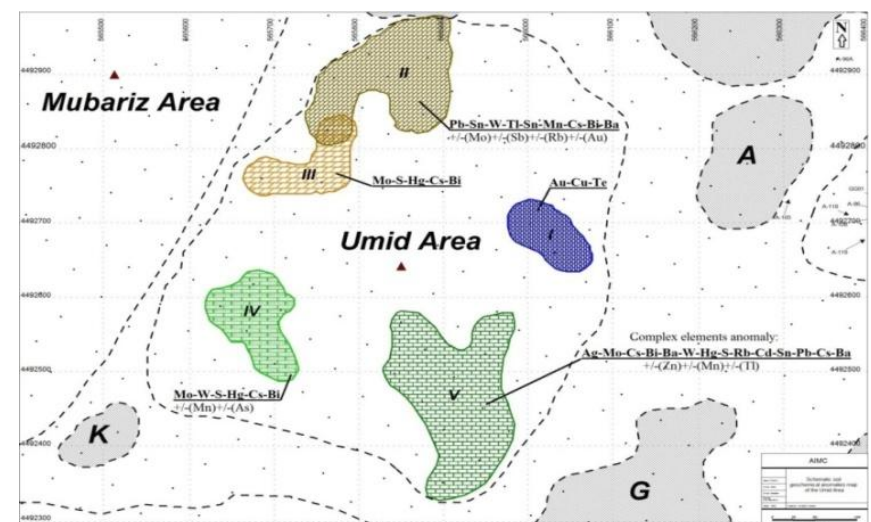

Figure5. Soil geochemical anomaly map for complex elements of Umid Area.

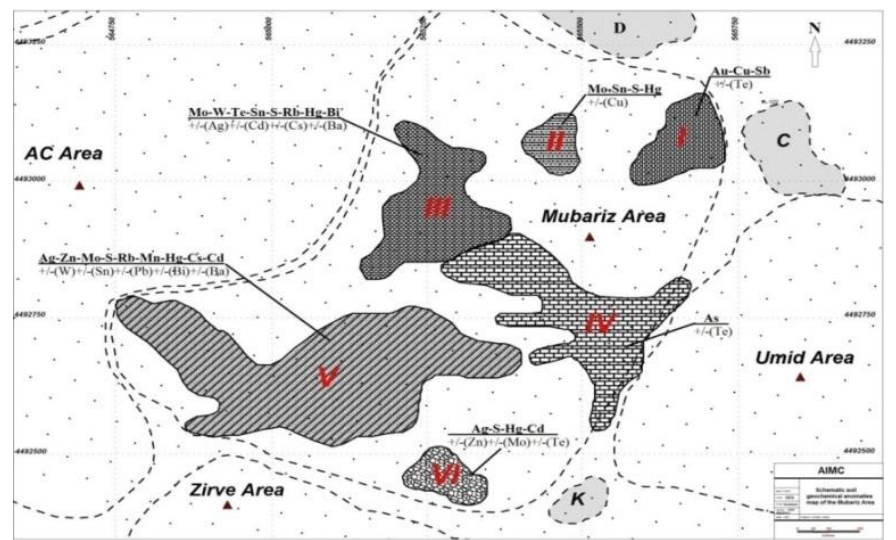

Figure6. Soil geochemical anomalies map of complex elements for Mubariz Area.

Table1. Soil geochemical signatures in the Gadir Gallery, Gadir, Umid, Mubariz Areas.

\begin{tabular}{|c|c|c|c|c|c|}
\hline Locality & Category & $\begin{array}{l}\text { Main ore } \\
\text { elements }\end{array}$ & $\begin{array}{c}\text { Description } \\
\text { mineralization models }\end{array}$ & Pathfinder elements & $\begin{array}{c}\text { Depth of } \\
\text { ore, } m\end{array}$ \\
\hline $\begin{array}{c}\text { Gadir Gallery } \\
\text { Area }\end{array}$ & $\begin{array}{c}\text { occurrenc } \\
\mathrm{e}\end{array}$ & $\mathrm{Au}, \mathrm{Ag}, \mathrm{Cu}$ & Low porphyry $\mathrm{Cu}$ & $\frac{\text { Au-Ag-As-Zn-Pb-Mo-Te-Ba }}{ \pm(\mathrm{Cu}) \pm(\mathrm{W}) \pm(\mathrm{Sn}) \pm(\mathrm{Tl}) \pm(\mathrm{Hg})}$ & $5-20$ \\
\hline Gadir Area & deposit & $\mathrm{Au}, \mathrm{Ag}, \mathrm{Zn}$ & Epithermal deposit & 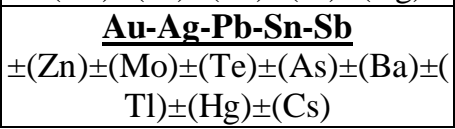 & 225-350 \\
\hline \multicolumn{6}{|c|}{ Umid Area } \\
\hline I. East Part & prospect & & & $\underline{\mathrm{Au}-\mathrm{Cu}-\mathrm{Te}}$ & \\
\hline II. North Part & prospect & & & $\frac{\text { Pb-Sn-W-Tl-Sn-Mn-Cs-Bi-Ba }}{ \pm(\mathrm{Mo}) \pm(\mathrm{Sb}) \pm(\mathrm{Rb}) \pm(\mathrm{Au})}$ & \\
\hline III. NW Part & prospect & & & Mo-S-Hg-Cs-Bi & \\
\hline IV. West Part & prospect & & & $\frac{\text { Mo-W-S-Hg-Cs-Bi }}{ \pm(\mathrm{Mn}) \pm(\mathrm{As})}$ & \\
\hline V. South Part & prospect & & & $\frac{\text { Ag-Mo-Cs-Bi-Ba-W-Hg-S- }}{\frac{\text { Rb-Cd-Sn-Pb-Cs-Ba }}{ \pm(\mathrm{Zn}) \pm(\mathrm{Mn}) \pm(\mathrm{Tl})}}$ & \\
\hline
\end{tabular}


Geochemical Anomalies in the NW Flank of Gedabek Mine (Lesser Caucasus, Azerbaijan)

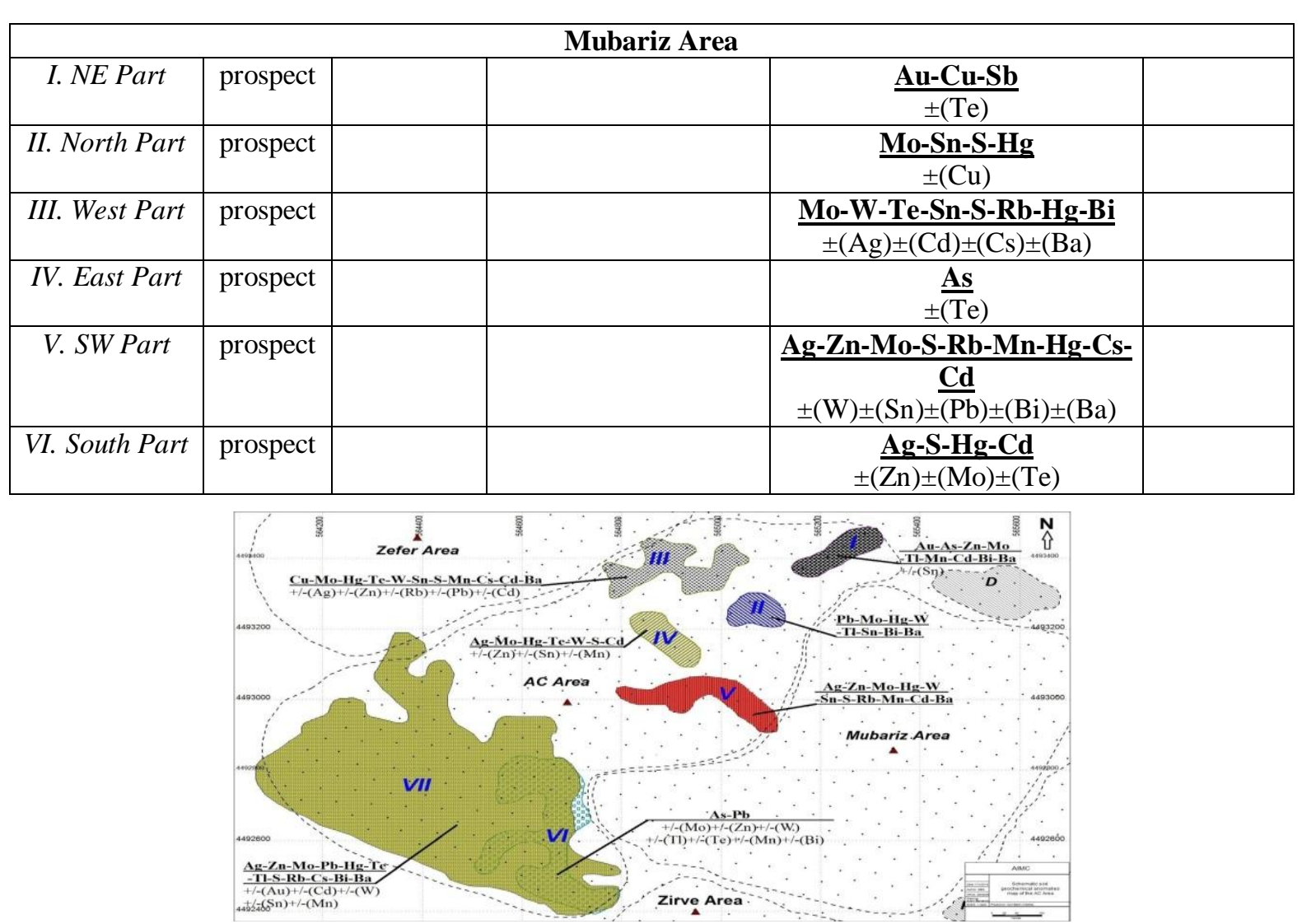

Figure7. Soil geochemical anomalies map for complex elements in the AC Area.

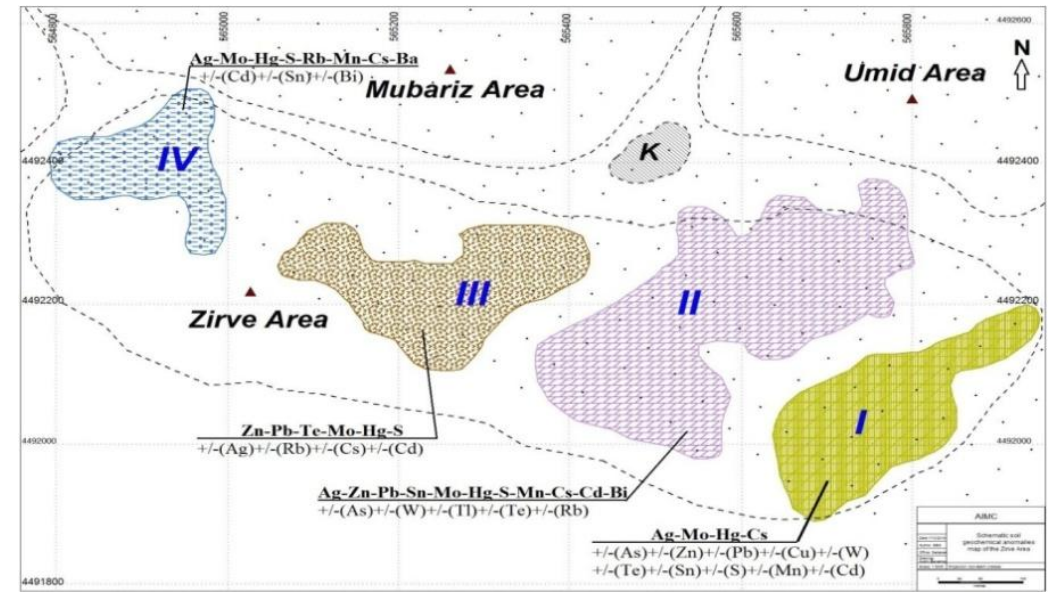

Figure8. Soil geochemical anomalies map for complex elements in the Zirve Area.

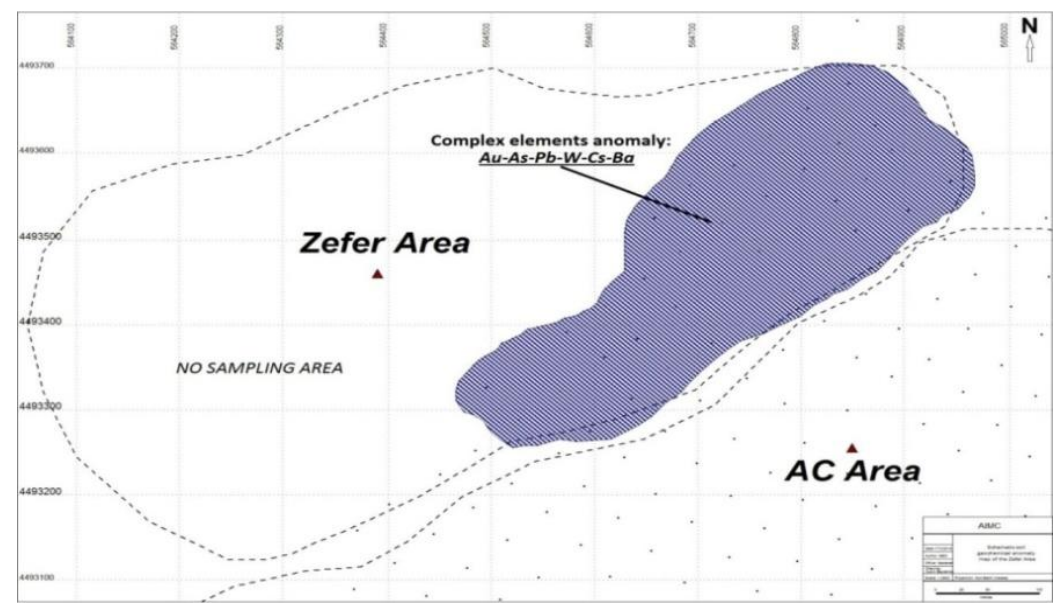

Figure9. Soil geochemical anomalies map for complex elements in the Zefer Area. 
Table4. Soil geochemical signatures in the AC, Zirve, Zefer Areas.

\begin{tabular}{|c|c|c|c|c|c|}
\hline Locality & $\begin{array}{c}\text { Catego } \\
\text { ry }\end{array}$ & $\begin{array}{l}\text { Main } \\
\text { ore } \\
\text { eleme } \\
\text { nts }\end{array}$ & $\begin{array}{c}\text { Descriptio } \\
\mathbf{n} \\
\text { mineraliz } \\
\text { ation } \\
\text { models }\end{array}$ & Pathfinder elements & $\begin{array}{l}\text { Depth of } \\
\text { ore, } \mathbf{m}\end{array}$ \\
\hline \multicolumn{6}{|c|}{ AC Area } \\
\hline I. NE Part & prospect & & & $\frac{\text { Au-As-Zn-Mo-Tl-Mn-Cd-Bi-Ba }}{ \pm(\mathrm{Sn})}$ & \\
\hline $\begin{array}{l}\text { II. North } \\
\text { Part }\end{array}$ & prospect & & & Pb-Mo-Hg-W-Tl-Sn-Bi-Ba & \\
\hline III. NW Part & prospect & & & $\frac{\text { Cu-Mo-Hg-Te-W-Sn-S-Mn-Cs-Cd-Ba }}{ \pm(\mathrm{Ag}) \pm(\mathrm{Zn}) \pm(\mathrm{Rb}) \pm(\mathrm{Pb}) \pm(\mathrm{Cd})}$ & \\
\hline $\begin{array}{l}\text { IV. Centre } \\
\text { Part }\end{array}$ & prospect & & & $\frac{\text { Ag-Mo-Hg-Te-W-S-Cd }}{ \pm(\mathrm{Zn}) \pm(\mathrm{Sn}) \pm(\mathrm{Mn})}$ & \\
\hline V. East Part & prospect & & & Ag-Zn-Mo-Hg-W-Sn-S-Rb-Mn-Cd-Ba & \\
\hline $\begin{array}{l}\text { VI. South } \\
\text { Part }\end{array}$ & prospect & & & 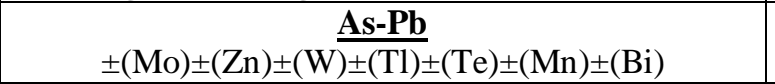 & \\
\hline VII. SW Part & prospect & & & $\frac{\text { Ag-Zn-Mo-Pb-Hg-Te-Tl-S-Rb-Cs-Bi-Ba }}{ \pm(\mathrm{Au}) \pm(\mathrm{Cd}) \pm(\mathrm{W}) \pm(\mathrm{Sn}) \pm(\mathrm{Mn})}$ & \\
\hline \multicolumn{6}{|c|}{ Zirve Area } \\
\hline I. East Part & prospect & & & $\begin{array}{c}\frac{\text { Ag-Mo-Hg-Cs }}{(\mathrm{As}) \pm(\mathrm{Zn}) \pm(\mathrm{Pb}) \pm(\mathrm{Cu}) \pm(\mathrm{W}) \pm(\mathrm{Te})} \pm(\mathrm{Sn}) \pm(\mathrm{S}) \pm(\mathrm{Mn}) \pm( \\
\mathrm{Cd})\end{array}$ & \\
\hline $\begin{array}{l}\text { II. North } \\
\text { Part }\end{array}$ & prospect & & & $\frac{\text { Ag-Zn-Pb-Sn-Mo-Hg-S-Mn-Cs-Cd-Bi }}{ \pm(\mathrm{As}) \pm(\mathrm{W}) \pm(\mathrm{Tl}) \pm(\mathrm{Te}) \pm(\mathrm{Rb})}$ & \\
\hline $\begin{array}{l}\text { III. Centre } \\
\text { Part }\end{array}$ & prospect & & & $\frac{\text { Zn-Pb-Te-Mo-Hg-S }}{ \pm(\mathrm{Ag}) \pm(\mathrm{Rb}) \pm(\mathrm{Cs}) \pm(\mathrm{Cd})}$ & \\
\hline $\begin{array}{l}\text { IV. West } \\
\text { Part }\end{array}$ & prospect & & & $\frac{\text { Ag-Mo-Hg-S-Rb-Mn-Cs-Ba }}{ \pm(\mathrm{Cd}) \pm(\mathrm{Sn}) \pm(\mathrm{Bi})}$ & \\
\hline \multicolumn{6}{|c|}{ Zefer Area } \\
\hline NE Part & prospect & & & $\begin{array}{c}\frac{\text { Au-As-Pb-W-Cs-Ba }}{ \pm(\mathrm{Zn}) \pm(\mathrm{Mo}) \pm(\mathrm{Hg}) \pm(\mathrm{Tl}) \pm(\mathrm{Te}) \pm(\mathrm{Sn}) \pm(\mathrm{Sb})} \pm(\mathrm{Rb}) \pm(\mathrm{Mn} \pm \\
(\mathrm{Cd}) \pm(\mathrm{Bi})\end{array}$ & \\
\hline
\end{tabular}

\section{CONCLUSION}

1. Gadir Gallery Area. The proximity of ore body to surface and suitable condition for element migration form soil geochemical anomaly for complex elements such as Au-Ag-As- $\mathrm{Zn}-\mathrm{Pb}-\mathrm{Mo}-\mathrm{Te}-\mathrm{Ba}$ in this area. There is planning to drill several underground drill holes in drifting gallery for check the possibility of ore in the deep levels (fig. 10).

2. Gadir Area. The anomaly of complex elements such as Au-Ag-Pb-Sn-Sb is located to the West from discovered ore body in Gadir area (fig. 10). This may refer to andesitic composition tuffs having structure elements deeping to South and South-West (Silitoe, Smitson, 2010 year). Each element such as $\mathrm{Zn}-\mathrm{Mo}-\mathrm{Te}-\mathrm{As}-\mathrm{Ba}-\mathrm{Te}-\mathrm{Hg}$-and $\mathrm{Cs}$ individually form anomaly around Gadir area. It may be connected with the element migration through intensive cracks and faults. The drilled drill holes in Gadir area were not completely bordered the ore and availability of element anomalies may indicate to other hidden ore bodies at the deep. There is planning to continue exploration works by gallery drifting and drilling drill holes in Gadir area.

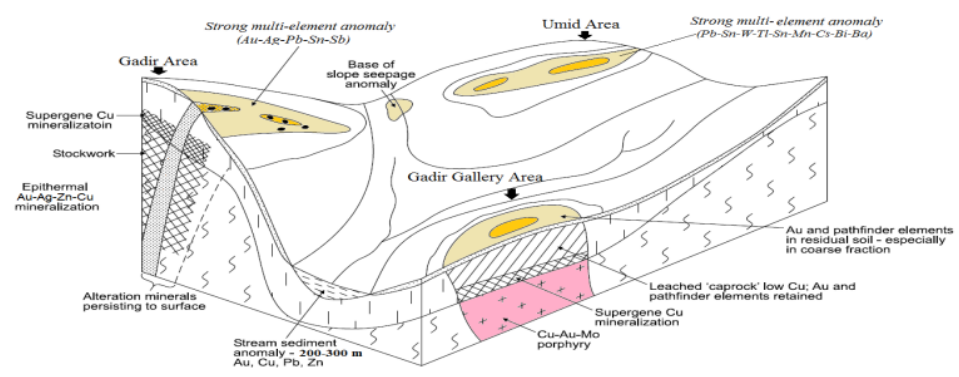

Figure10. Dispersion model for Gadir Gallery, Gadir and Umid Area. 
3. Umid Area. In Umid area were discovered 5 anomaly areas for complex elements. The variety of elements that make up these anomalies may be due intensive hydrothermal alteration on this area. The anomalies location looks like ring system and it can indicate on new sub volcanic body and variability of ore in contact between sub volcanic body and volcanic rocks.

4. Mubariz Area. Discovering 6 individual anomalies for complex elements and the variety of elements that make up these anomalies, can indicate on a hidden ore at the deep. Especially the abundance of ore indicator-elements and the footprint of each individual anomaly also increase the ore perspective of this area. Also the area looks like rise and is perspective in structural point of view.

5. AC Area. One big and six relatively smaller anomaly areas were discovered in AC area. Anomaly number 7 is the biggest anomaly and consist of elements such us Ag-Zn-Mo-Pb-Hg-Te-Tl-S-Rb-Cs$\mathrm{Bi}-\mathrm{Ba}$. This anomaly increases the perspective of ore in South-West contact between rhyolite sub volcano (Quartz Porphyry) and volcanic rocks. In structural point of view AC area is located between two mountain ranges (Gyzyldjadag and Yogundag). One of them (Gyzyldjadag) acidic composition, other (Gyzyljadag) is moderate composition and location of AC area in contact between these two mountain ranges also increases the ore potential of $\mathrm{AC}$ area.

6. Zirve Area. This area is situated on the west part of the Gedabek-Bittibulag fault. Four anomaly areas for complex element were discovered on the Zirve area. Each anomaly consistencies to erosion caldera. It should be investigate the following issues:

- Forming these anomalies under the influence of carbonate coming through little break and cracks from hidden ore bodies

- Forming these anomalies due to weathering syngenetic ore minerals in breccias which is in volcanoclastic of volcano crater.

Mubariz, AC and Zirve anomaly areas coincide with each other by the complex element compositions. The East flanks of Mubariz and AC areas are surrounded by As anomaly. The valleys which splitted the anomalies is constantly eroded. If consider the similarity of complex elements composition and the same eroded valleys we can get the big anomaly area if we join these tree anomaly.

Base on international geological model and vertical section the location of As anomaly on the top horizons may be an arch part of the hidden ore body.

Zefer Area. The soil geochemical anomaly of complex elements such us Au-As-Pb-W-Cs-Ba can be interesting from ore forming point of view. But the anomaly results of all samples and location near Gedabek-Bittibulag fault require to continue soil sampling in this area. These anomaly areas are, possibly, connected with lithology factor. Because, the rocks which occurred in North-West part of Gedabek deposit are completely different. If the andesite and andesite-basalt composition rocks are wide spread in North-West flank of Gedabek deposit, the rhyolite and rhyodacite composition rocks are wide spread in Zefer area. It is known that Clark content of elements in acidic composition rocks is more than the Clark content in moderate composition rocks. Due this, possible, this anomaly of most elements is observed in Zefer area.

\section{REFERENCES}

[1] Agakishiyev A., Chalabi H., Gadimov Sh., Akbarov M., Asgarov R., Report on work results on goldbearing assessment of Gedabek copper-pyrite deposit for the period of 1992-2002 years, Baku, 2004.

[2] AIMC Gedabek Exploration Group (GEG). Report about the results and future planning of the perspective areas ( $\mathrm{Au}, \mathrm{Ag}, \mathrm{Cu}, \mathrm{Mo}, \mathrm{Zn}$ ) of Gedabek Ore District, Gedabek, 2014.

[3] Musaev A.N. Gedabek deposit /chapter in report on results of prospecting-estimation works to copper in revealed perspective areas of Gedabek ore knot for 1977-1980 years/. Azerbaijan State Stock.

[4] Musaev A.N., Mustafazade B.V. Prospects of Gedabek deposit of gold-copper-porphyry ores and similar ore knot. Baku, 1995.

[5] Musaev A.N., Kurbanov N.A., Mustafazade B.V. Report on subject "Prospects of Gedabek deposit of gold-copper-porphyry ores and similar ore knot". Baku, Geological Stock of "Southern Central ScientificResearch Exploring Institute", 1996.

[6] Uspenskiy A.S. Gedabek type of copper deposits in the Caucasus. Saint-Petersburg, 1910.

[7] Butt C.R.M., Geochemical dispersion, process and exploration models, CRC LEME, CSIRO Exploration and Mining, P.O. Box 1130, Bentley, WA 6102, 2006 year. 
[8] Akhmedov D.M. Report on results of exploration party to copper in a central part of Shamkhor anticlinorium for 1969-1972 years. Azerbaijan State Stock.

[9] Shekinskiy E.M., Kerimov A.F. Report on the results of the detailed prospecting on copper-porphyry ores within the bounds of Gedabey-Bittibulag ore-bearing zone for 1979-1982 years, Baku, 1983.

[10] Guseynov G.S. Gold presence in copper-pyrite deposits of Somkhit-Garabakh zone /Lesser Caucasus/. Abstract of Ph.D. thesis. Baku, 1987.

[11] Mekhtiev G.I., Veliev N.N. Report on prospecting results to copper within perspective areas of Gedabek ore knot for 1977-1980 years. Azerbaijan State Stock.

[12] Peyman Afzala, Hamid Harati, Younes Fadakar Alghalandis, Amir Bijan Yasrebi, Application of spectrum-area fractal model to identify of geochemical anomalies based on soil data in Kahang porphyrytype $\mathrm{Cu}$ deposit, Iran, 2013.

[13] Reports on results of prospecting works in Gedabek deposit for 1956-1957 and 1956-1959 years. Azerbaijan State Stock.

Citation: Baba-Zadeh Vasif, et.al (2019)" Geochemical Anomalies in the NW Flank of Gedabek Mine (Lesser Caucasus, Azerbaijan)", Southeast Cameroon, International Journal of Mining Science (IJMS), 5(1), pp.31-42, DOI: http://dx.doi.org/10.20431/2454-9460.0501005

Copyright: (C) 2019 Authors. This is an open-access article distributed under the terms of the Creative Commons Attribution License, which permits unrestricted use, distribution, and reproduction in any medium, provided the original author and source are credited 